\title{
Legal Studies
}

To subscribe or recommend a subscription to your librarian

cambridge.org/legalstudies

Discover the entire Legal Studies back archive

cambridge.org/legalstudies/read

Find out how to submit your paper

cambridge.org/legalstudies/ifc

To advertise in the journal

ad_sales@cambridge.org

Copyright and permissions

cambridge.org/about-us/rights-permissions

Abstracting and indexing services

cambridge.org/legalstudies/ai

Claims and address updates

subscriptions_newyork@cambridge.org (in the USA, Canada and Mexico)

journals@cambridge.org (elsewhere)

\author{
Follow Legal Studies on Twitter \\ @legalscholars
}

Printed in the UK

by Bell \& Bain Ltd., Glasgow

\section{Proper citation}

Legal Studies should be cited as: (2019) 39 LS 


\section{CONTENTS}

Winner of the SLS Annual Conference Best Paper Prize 2020

Beyond acts and omissions: remark-able criminal conduct Mark Dsouza

\section{Research Articles}

Reasonable accommodation in Irish equality law:

an incomplete transformation

Lucy-Ann Buckley and Shivaun Quinlivan

Homelessness and the 'over-judicialisation' of welfare

Emma Laurie

The end to testamentary freedom

Richard Hedlund

The conflict between market competition and worker solidarity: moving from consumer to a citizen welfare standard in competition law

Firat Cengiz

Criminalising deceptive sex: sex, identity and recognition Chloë Kennedy

An analysis of three distinct approaches to using defamation to protect corporate reputation from Australia, England and Wales, and Canada

Peter Coe

Is the incompatibility of UK data retention law with EU law really a victory?

Matthew White

Obligations, consent and contracts in Scots law:

re-analysing the basis of medical malpractice liability in light of Montgomery $v$ Lanarkshire Health Board Jonathan Brown

\section{Cambridge Core}

